\title{
Factor Affecting Beef Cattle Value Chain Analysis in Nono Benja District, Jimma Zone, Oromia Regional State, Ethiopia
}

\author{
Gemechu Degefa Yadata (M.Sc.) $^{*} \quad$ Adeba Gemechu (PHD) Amsalu Mitiku (PhD) \\ Jimma University, PO box 307, Jimma, Ethiopia
}

\begin{abstract}
Ethiopia ranks first in Africa and tenth in the world for livestock population and cattle take the lion share of this population of the country. This study was conducted in Nono benja district of Jimma zone, Oromia regional state, Ethiopia with the aim of analyzing and identifying factors affecting beef cattle market supply. Two stage sampling methods were employed to select producers and data were collected from both primary and secondary sources. Primary data were collected from 154 producers, and 20 small traders, 5 large traders, 6 butchers, 8 hotels /restaurants/ and 30 consumers while secondary data were collected from the district and other government organizations. Descriptive statistics and econometric model were used to analyze the data using STATA 13 software. The finding of the study revealed that the multiple liner regression model result revealed that, education, distance to market, use credit, access to market information, distance to nearest feed resources and livestock owned influences market supply significantly. Generally, the existing situation for beef cattle sector with regard to its value chain analysis, integration and coordination is not well stimulated in the area. Therefore, policy aiming at facilitating producer's education, distance to the market, use credit, access to market information, distance to feed resources, number of livestock owned, strengthening the existing sector and improving linkage of chain actors are recommended to enhance the development of beef cattle value chain at Nono Benja district of south western, Ethiopia.
\end{abstract}

Keywords: Value Chain, actors, beef cattle, Multiple liner regression model and Nono Benja district.

DOI: $10.7176 / \mathrm{JBAH} / 10-3-04$

Publication date: February $29^{\text {th }} 2020$

\section{INTRODUCTION}

\subsection{Background}

The majority of the world's estimated 1.3 billion poor people live in developing countries where they depend directly or indirectly on livestock for their livelihoods (World Bank, 2013 and FAO, 2012). Globally, livestock contributes about 40 percent to the agricultural gross domestic product (GDP) and constitutes about 30 percent of the agricultural GDP in the developing world (World Bank, 2013). They keep livestock and use them in a variety of ways that extend far beyond income generation. In many cases, livestock are a central component of smallholder risk management strategies (Bailey et al., 2015).

The sector plays a major role in the national economy and it is the source of income and employment for the rural population (Nigussie, 2014). Livestock production is an integral part of Ethiopia's agricultural sector and plays a vital role in the national economy. At present, livestock contributes about $20 \%$ of the GDP, supporting the livelihoods of $70 \%$ of population and generating about $11 \%$ of annual export earnings. As the country has a large livestock population, which ranks first in Africa and tenth in the world, it has much to gain from the growing global markets for livestock products (SPS-LMM, 2010).

Global beef production was estimated at 55 million tons in 2010 (FAPRI-ISU, 2015), with 75 percent of this beef being produced in Brazil, China, the EU and the United States. The longer-term outlook for global beef demand is, however, positive, with a rise in beef demand of 10 million tons forecast over the next decade (Rabobank, 2010). There is an urgent need to improve livestock productivity in Ethiopia in order to keep pace with expected increase in demand for livestock products. Demand for beef in sub-Saharan Africa, almost doubled over the past two decades. The same trend has been observed in eastern Africa. Unfortunately, livestock productivity remains very low compared to other parts of the world because producers are beset by several technical, institutional and infrastructural constraints related to feeding, animal health and genotype (Oume et al., 2010).

In 2008/09, Ethiopian sedentary private holdings were estimated at about 49 million heads of cattle (CSA, 2009). Potential areas identification and effective documentation of traditional practices are excellent premises for improvement of the beef sector in Ethiopia. like most of the countries in sub-Saharan Africa, is heavily dependent on agriculture. The agricultural sector plays an important role in the overall development of the country's economy. The sector plays a major role in the national economy and it is the source of income and employment for the rural population (Nigussie, 2014).

The recent livestock population of Ethiopia estimates that the country has about 52.1 million heads of cattle, 24.2 million sheep, 22.6 million goats and 44.9 million poultry (MOA, 2013; Berihu et al., 2014). The majority of the world's rural poor, and a significant proportion of the urban poor, keep livestock and use them in a variety 
of ways that extend far beyond income generation. The roles livestock play in developing countries, especially to rural livelihood improvement and augmenting livelihood of poor, are well recognized (Upton, 2014).

According to MOFED (2009) and World Bank (2002) the economic contribution of the livestock sub-sector in Ethiopia is also about $15 \%$ to $17 \%$ of GDP and $35 \%$ to $49 \%$ of agricultural GDP, and 37 to $87 \%$ of the household incomes. Formally, Ethiopia exports about 472,000 Livestock annually (MoA, 2011 and LLC, 2011). This is significantly higher than the annual official exports of cattle (12,934 head), sheep (13,554 head) and goats (1,247 head) between 1998 and 2003 (Kefyalew,2011). In Ethiopia, recent studies estimated that annual illegal flow of livestock through boundaries reaches as high as 575,000 cattle, 1,150.000 Shoats \& 126,500 Camel (Solomon et al., 2010 and LMD Research, 2013).

Particularly highland mixed crop-livestock farming system of Ethiopia support $2 / 3$ of the livestock population and hold about $95 \%$ of the cropped area. It is estimated that the highlands contain nearly 75 to $80 \%$ of the national cattle and sheep, and $30 \%$ of the national goat flock (Hailesilassie, 2016). His being the potential for export, the actual performance has remained very low, leaving most (55 to 85\%) of the projected livestock off take for the unofficial cross-border export and the domestic market.

More over areas like Borena and pastoral 2 areas where value of live cattle as draught animal is of little importance are valuable sources of beef cattle (Takele et al., 2009). According to AGP-LMD (2013) in Ethiopia a number of producers, collectors and traders complained about illegal trader or unlicensed individuals without previous market knowledge who were acting as brokers. The limited market information available to the value chain actors (particularly to the small producers who visit the market once or twice a year and the small traders) allows the unlicensed broker to manage information in his favor thereby distorting the market in their favor.

Generally, the Oromia region has a huge number of livestock populations. Of which with the current estimate the cattle constitute about 22.35 million, of this according Jimma Zone has about 3,604,870 million among this dairy and beef cattle accounted 2,193,372 sheep's 836,596 goats 439,193 and equines 183,306 (Jimma Zone livestock development offices 2017) and again According to Yigezu et al 2014 livestock population of Jimma zone accounted 2.540,225 million on the study conducted south western part of the country.

Among this Nono Benja district cattle accounted 230,000 sheep's 65,000 goats, 36,000and equines 55,127 (Nono benja livestock development offices,2017). Value chain analysis facilitates an improved understanding of competitive challenges, helps in the identification of relationships of actors and coordination mechanisms, and assists in understanding how chain actors deal with powers and who governs or influences the chain. Similarly, it is also essential to explain the connection between all the actors in a particular chain of production and distribution and it shows who adds value more and where, along the chain. It helps to identify pressure points and make improvements in weaker links where returns are low (Gashahun, 2015).

\subsection{Statement of the Problem}

The livestock sector in Ethiopia plays a vital role in the overall development of the country's economy. Yet, the existing income generating capacity of livestock as compared to its immense potentials in the country is not encouraging. Under these conditions, farmers have no incentives to improve the quality of their animals through appropriate management practices (Solomon, 2004). To enhance opportunities for value chain actors, we need to understand the main value chain actors affecting the entire value chain (Berhanu, 2012).

Total meat consumption was close to $276 \mathrm{t}$ in $2006-07$, of which beef account for $68 \%$. Pronounced differences have been identified between rural and urban patterns of meat consumption, particularly for beef (1.7 $\mathrm{kg}$ and $7.0 \mathrm{~kg}$, respectively) (Negassa and Jabbar, 2008). Overall production for sale has proven difficult to estimate, but production and export volumes indicate approximate self-sufficiency in beef, necessitating exports as an outlet for any future increases in production. However, meat production per head of livestock is low by the standards of other significant livestock producing African countries (Gebremariam et al., 2013). For instance, de Haan (2013) shows that production of cattle meat in Ethiopia is just $8.5 \mathrm{~kg} / \mathrm{head}$ of cattle per year, which is significantly lower than in Kenya and Senegal (21 and $16 \mathrm{~kg}$, respectively).

Systematic identification of constraints faced by beef cattle value chain is increasingly seen by agricultural research as important component of any strategy for reaching the Millennium Development Goals (MDG) (Giuliani and Pietrobelli, 2005). Such information provides useful insights towards the designing and implementation of strategies to alleviate the shortage of quality beef cattle supply in the market (Gebremariam et al., 2013)

Even though the high potential of beef cattle production in study areas the producers use as a source of cash income from their animal they should have to be known season of production and time of high demand of their beef in each value chain actors throughout the beef value chain of the country. In general, and the study area in particular, they are not considered well and acknowledged by the responsible bodies to upgrade the commodity transformation into better stage and which can pay back positive return to the whole economy.

In this regard, beef value chain analysis is an interesting process but as far as known very limited investigation has been done in the study area. Under such circumstances, a study that focused on production and 
marketing problems, and roles and responsibilities of actors can play significant role towards the improvements of the existing system.

In the study area market linkage service like; relation among producers, traders controlling mechanisms, market information and price settings are weak and it need critical investigation. Value chain analysis enables to understand the relationship among input suppliers, producers and other actors. Despite, this study was aimed to fill information gaps factors affecting quantity market supply of beef cattle in the study areas.

Therefore, this study helps to narrow the research gap on the subject and contribute towards improvement of strategies for reorienting value chain system and helps to generate information that can help as input for making an informed intervention to improve the system.

\subsection{Research Questions}

* What are the factors affecting quantity of beef cattle market supply in the study areas.

\subsection{General objective}

\subsubsection{Specific objectives}

* The study factor affecting beef value chain in Nono Benja district, Jimma Zone Oromia regional state, Ethiopia.

$\checkmark \quad$ To identify factors affecting quantity of beef market supply in the study area.

\section{RESEARCH METHODLOGY}

This chapter deals with description of the study area, data types and method of data collection, sampling procedures, method of data analysis (descriptive statistics, econometric analysis and definition of variables and research hypothesis (including the dependent and independent variables).

\subsection{Description of the Study Area \\ Map of the study Area}

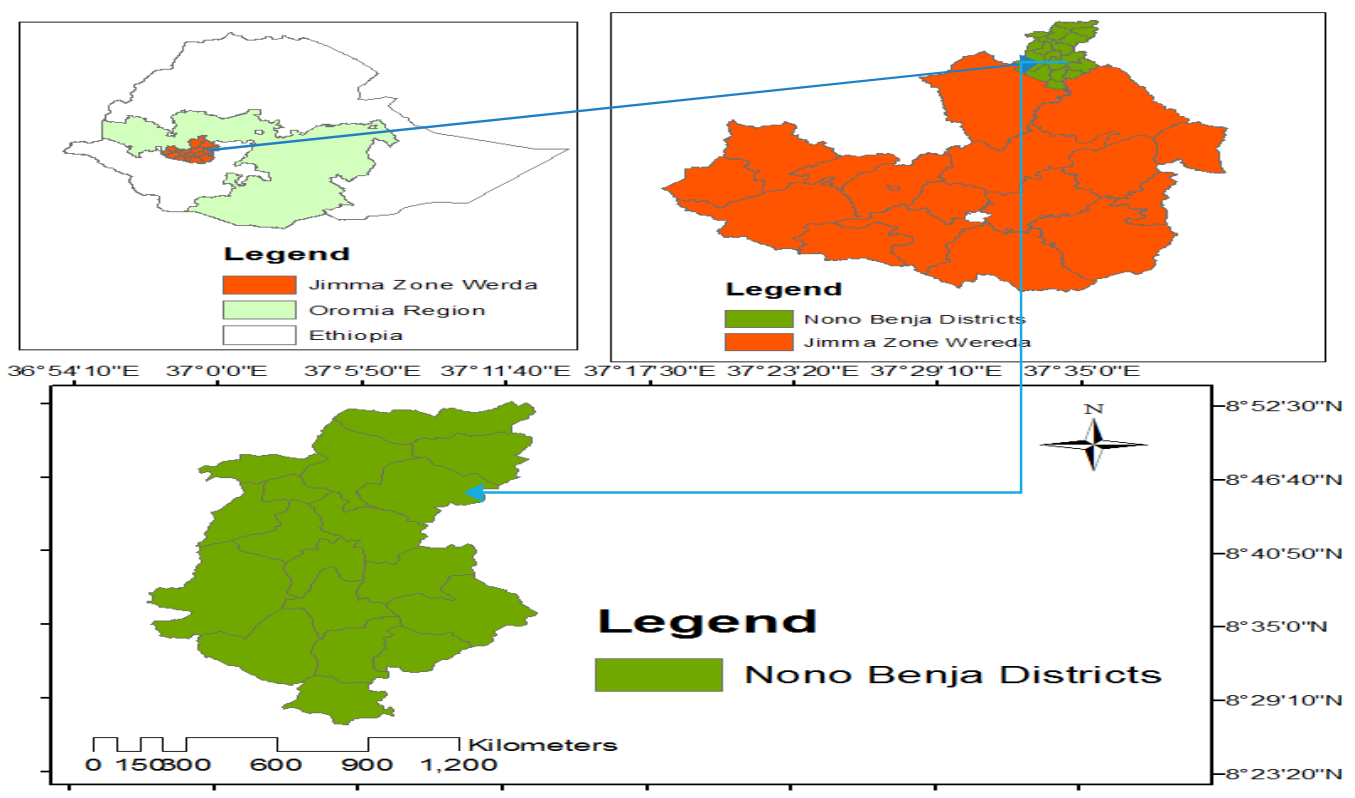

Figure 4 Map of the study area.

\subsection{Types, Sources and Methods of Data Collection}

\subsubsection{Data types and sources}

For this study, both qualitative and quantitative types were collected from primary and secondary sources. A qualitative method was used to collect the qualitative type such as data collected through focus group discussion and key informant interview. A quantitative method was used to collect information that has been transformed into numbers such as demographic, institutional, and socio-economic factors.

2.2.2 Methods of data collection

Primary data: The data were collected through formally by the method of individual interview using structured 
and semi-structured using questionnaire, focus group discussion and key informants using checklists and observations from concerned agents and model farmers by using data collectors.

Secondary data: The Data were gathered from published materials, district agriculture and rural development offices, livestock development offices, farmer's organization, districts industry and trade office and published and unpublished documents

\subsection{Sampling Procedure and Sample Size Determination}

2.3.1. Producers sampling

Two stages random sampling technique was used to select the target respondents because of all sampled kebeles and respondents are homogeneous. In the first stage, out of 19 kebeles in the district, a total of 4 beef cattle producer kebeles were randomly selected. In the second stage, using beef cattle fatteners farmers from the sampled kebeles, 154 sample smallholder producers were selected randomly based on Probability to proportional size by using Yamane (1967) formula.

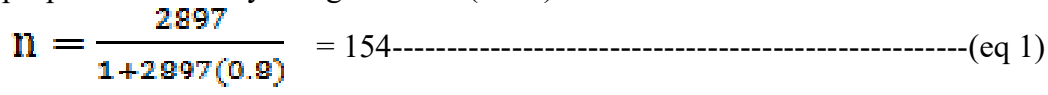

Where, $\mathrm{n}=$ sample size

$\mathrm{N}=$ total number of beef cattle fatteners of districts

$\mathrm{e}=$ level of precision at $8 \%$

The determination of sample size was resolved using Yamane (1967:886), simplified formula to calculate the sample size with the desired confidence level of $95 \%$

Sampling error: The maximum expected difference between a probability sample value and the true value (EPA, 2008). At a confidence level of $95 \%$, sampling error is generally recommended to be less than $10 \%$ for reliability purposes.

Confidence interval: An estimate of a population parameter that consists of a range of values bounded by statistics called upper and lower confidence limits, within which the value of the parameter is expected to be located (EPA, 2008).

As the variability in the population was not known before hand, the maximum variability (50\%) was taken in the current study. Often, an acceptable margin of error used by survey researchers falls between $4 \%, 5 \%, 7 \%$ and $8 \%$ at the $95 \%$ confidence level (Data Star, 2008). So a margin of error of $8 \%(0.08)$ was taken for this study. Table 1. Summary of the sample size of livestock fatteners households

\begin{tabular}{lccc}
\hline \hline Name of Kebeles & $\begin{array}{c}\text { Total household size } \\
\text { fatteners }\end{array}$ & sample ( $\mathrm{n})$ & Proportion (\%) \\
\hline Ilu & 586 & 42 & 27.14 \\
Ilfata & 530 & 39 & 25.19 \\
Roggee & 489 & 37 & 23.78 \\
Ebicha & 492 & 38 & 23.88 \\
Total & 2097 & 154 & 100.00 \\
\hline \hline
\end{tabular}

Source: Own computation from secondary information (2018)

\subsection{Method of Data Analysis}

Both descriptive statistics and econometric analysis were employed to analyze the data collected from all actors involved in beef value chain and marketing of the study area.

\subsubsection{Descriptive statistics}

Descriptive statics such as mean, maximum, minimum, standard deviation, frequencies and percentages were used in the process of examining and describing the socio-economic and demographic characteristics of the producers.

\subsubsection{Econometric analysis}

Econometric analysis was used to estimate the causal relationship between the dependent variable and the explanatory variables. Econometric analysis of the data was done with Stata 13 software. Econometric model specification of supply function in matrix notation is the following

Multiple liner regression model

Multiple linear regression models were fixed to survey data to generate information about factors influence beef cattle supply to the market. A regression with two or more explanatory variables is called a multiple regression. Rather than modeling the mean response as a straight line, as in simple regression, it is now modeled as a function of several explanatory variables.

In this study, multiple linear regression models were used to analyze factors affecting number of beef cattle supply to the market in the study areas if all beef cattle producers participate in the market. Econometric model specification of supply function in matrix notation is the following. 
$\mathrm{Y}=\mathrm{X} \beta+\mathrm{U}$

Where:

$\mathrm{Y}=$ number of beef cattle fatting supplied to market $\mathrm{Y}$

$\mathrm{X}^{\prime}=$ Vectors of explanatory variables $\mathrm{X}^{\prime}$

$\beta=$ a vector of parameters to be estimated

$\mathrm{U}=$ disturbance term $\mathrm{U}$

When the assumptions of the Classical Linear Regression (CLR) model are violated, the parameter estimates of the OLS model may not be Best Linear Unbiased Estimator (BLUE). Hence, it is important to check the presence of multicollinearity and heteroscedasticity among the variables which are proposed to affect number of beef cattle market supply in the study area. Therefore, before fitting variables into the model for analysis, it is necessary to test multicollinearity problem among continuous variables and check associations among discrete variables, which seriously affects the parameter co estimates.

Test for multicollinearity: -multicollinearity refers to a situation where it becomes difficult to identify the separate effect of independent variables on the dependent variable because their strong relationship among them. or it is a situation where explanatory variables are highly correlated. Tolerance and Variance Inflation Factor (VIF) for a continuous variables association and Contingency Coefficients (CC) for dummy variables association are the two measures testing the existence of multicollinearity (Gujarati, 2003).

Tolerance (TOL) and Variance Inflation Factor (VIF): - As $\mathrm{R}^{2}$ increases towards one that is as the collinearity of regressor $\mathrm{Xj}$ with other regressors increases its variance inflation factor (VIF) also increases and in the limit, it can be infinite. The larger the value of VIF, the more collinear is the variable $\mathrm{Xj}$.

Interpretation, if the VIF of a variable exceeds 10 (this will happen if $\mathrm{R}^{2}$ exceeds 0.90 ), that variable is said to be highly collinear (Gujarati, 2003). Tolerance (TOL) can also be used to detect multicollinearity. Clearly, $\mathrm{TOL}_{\mathrm{j}}$ is one if $\mathrm{X}_{\mathrm{j}}$ is not correlated with the other regressors, whereas it is zero if it is perfectly related to other regressors. $\mathrm{VIF}=\mathrm{VIF}-$

Contingency Coefficient: - is a symmetric measure which indicates the strength and significance of the relation between the row and column variables of a cross tabulation. The value ranges between zero and one, with zero indicating no association between the row and column variables and values close to one indicating a high degree of association between the variables. Contingency coefficient analysis was carried out to check for the strength of relationship among discrete variables. The decision criterion is that variables with contingency coefficient closer to one would be avoided from further consideration in the analysis.

Test for heteroscedasticity: -There are a number of test statistics for detecting heteroscedasticity. The major is Park, Breusch-Pagan, Godfrey, White's testes, Koenker-Bassett (KB) test of heteroscedasticity. According to Gujarati (2003), there is no ground to say that one test statistics of heteroscedasticity is better than the other test statistics. Due to its simplicity, Koenker-Bassett (KB) test of heteroscedasticity was employed for the analysis. However, if heteroscedasticity happened in the analysis, other optional robust standard error method would be employed since it can tolerate serious heteroscedasticity.

\subsection{Definition of Variable and Hypothesis}

The data are covering information necessary to make farm level indices of social-economic characteristics, beef cattle production and marketing and factors affecting Market supply.

\subsubsection{Dependent Variable}

Quantity of beef cattle supplied to the market: it is a continuous dependent variable and measured in quantity of beef supplied to the market during $2017 / 18$ by TLU.

\subsubsection{Independent variables}

Some of the major explanatory variables that are expected to determine market supply of beef cattle in the value chain of this study were the following: 
Table 2. Description of dependent and independent variable

\begin{tabular}{lllll}
\hline \hline Variables & Description & Types & Measurement & $\begin{array}{l}\text { Expected. } \\
\text { Sign }\end{array}$ \\
\hline NUMBBSUP & Number of beef cattle supply & - & - & - \\
BODCOND & Body condition of beef cattle & Dummy & Yes=1/ No=0 & + \\
LIVHH & Livestock holding of house hold & Continuous & TLU & + \\
DISFED & Distance to feed resource & Continuous & In walking hour/minute & - \\
NONFIN & Non-farm income house hold & Continuous & In birr & + \\
HHSIZE & House hold size & Continuous & In adult equivalent & $+/-$ \\
EXPER & Experience of house hold & Continuous & In years & + \\
DISMKT & Distance to nearest market & Continuous & In kilometer & - \\
MKTINF & Access of Market information & Dummy & Yes=1/No=0 & + \\
FREXTCON & Frequency to extinction contact & Continuous & How many t/week & + \\
USCRED & User credit & Dummy & Yes=1/No=0 & + \\
LSIZE & Land size & Continuous & In hectare & + \\
EDUCHH & Education level of house hold & Continuous & Schooling Years & + \\
\hline \hline
\end{tabular}

Source; Own computation 2018

\section{RESULTS AND DISCUSTION}

This section deals with the major outcomes of the study. It is divided into five main sections. The first section deals with descriptive statistics of the sample households. The second section presents value chain analysis of beef which includes actors and their roles, value chain map. The third section presents share of value chain actors in market channels benefit shares of actors. The fourth section presents result of econometric analysis which contains factors affecting market supply of beef by using Multiple linear regression model. The fifth section deals with the constraints and opportunities of beef value chain in the study area.

\subsection{Descriptive Results}

3.1.1 Demographic and socio economic characteristics of producers.

Demographic and socioeconomic characteristics of the sample respondents, the total sample size of farm respondents handled during the survey were 154.

Table 3. Demographic and socio- economic Characteristics of Producers

\begin{tabular}{lllll}
\hline Variable & Mean & Std. Dev. & Min & Max \\
\hline Quantity of beef supply & 2.243243 & 1.047327 & 1 & 5 \\
Livestock holding & 11.07905 & 3.928567 & 2.9 & 21.8 \\
Distance from feed resources & 12.14865 & 5.279101 & 3 & 30 \\
Non-farm in come & 4119.595 & 4440.927 & 0 & 30000 \\
House hold family size & 4.015203 & 2.944044 & 1.3 & 10.2 \\
Experiences & 3.263514 & 2.277848 & 1 & 14 \\
Distance from market center & 9.182432 & 5.10407 & 1 & 23 \\
Total land size & 3.041892 & 1.937642 & .5 & 10 \\
Education of house hold & 4.932617 & 2.559559 & 0 & 10 \\
Body condition of animal & $\mathbf{N}$ & & & $\%$ \\
Good & 115 & & & 74.67 \\
Not good & 39 & & & 25.35 \\
\hline \hline
\end{tabular}

Source; Owen Survey Result 2018 
3.2.1 Service availability

Table 4. Service provision

\begin{tabular}{lll}
\hline Description & Frequency & Percentage \\
\hline Frequency of extension contact & & \\
No extension contact & 26 & 16.88 \\
Once a month & 42 & 27.27 \\
Twice a month & 28 & 18.18 \\
Thrice a month & 23 & 14.93 \\
Fourth time a month & 35 & 22.72 \\
Access of market information & & \\
Yes & 98 & 63.63 \\
No & 56 & 36.36 \\
Credit & & \\
User & 89 & 57.79 \\
Non user & 65 & 42.21 \\
Total & $\mathbf{1 5 4}$ & $\mathbf{1 0 0 \%}$ \\
\hline \hline
\end{tabular}

Source: Owen Survey Result 2018

\subsection{Factors affecting quantity of supply of beef to the market}

The result from MLR is presented on Table 8 . The overall goodness of model fit is high $\left(\mathrm{R}^{2}=76.05 \%\right.$, ) indicating that over $76.05 \%$ of the variation in beef cattle quantity supplied is due to the hypothesized variables. The results of the multiple linear regression model suggest that market supply beef cattle production is significantly influenced by education, access market information, distance to nearest market, distance to feed resources, credit users and livestock holding significantly.

Table 4. Results of the Robust Multiple liner regression

\begin{tabular}{llcll}
\hline \hline Variables & Coef. & T. value & Std. Err. & P >t \\
\hline LIVHH & $.039^{* * *}$ & 3.28 & .0119 & 0.001 \\
BODCOND & .038 & 0.37 & .106 & 0.715 \\
DISFED & $.0190^{* * *}$ & 3.19 & .005 & 0.002 \\
NONFIN & $6.94 \mathrm{e}$ & 0.53 & .000 & 0.599 \\
HHSIZE & -.018 & -0.86 & .022 & 0.394 \\
EXPER & .036 & 1.41 & .025 & 0.162 \\
DISMKT & $-.076^{* * *}$ & -7.47 & .010 & 0.000 \\
MKTINF & $.368^{* * *}$ & 3.47 & .106 & 0.001 \\
FREXTCON & .017 & 0.34 & .050 & 0.732 \\
USCRED & $.2345^{* *}$ & 2.45 & .095 & 0.016 \\
LSIZE & .029 & 1.33 & .022 & 0.187 \\
EDUCHH & $.113^{* * *}$ & 4.21 & .027 & 0.000 \\
\hline CONS & 1.198 & 4.49 & .266 & 0.000 \\
\hline \hline
\end{tabular}

*** and** represent significant at $1 \%$ and $5 \%$ probability levels respectively

R-squared $=76.05 \%$ Adj R-squared $=73.46 \%$

Source: Own Survey Result 2018

Education of the Household Head (EDUCHH): As it was hypothesized before educational grade level of the household head affected market supply of beef positively and significantly at $1 \%$, thus, holding other factors constant, on average increases the level of education of the farmers increasing quantity of beef cattle supplied to the market by 0.113 TLU. Education broadens farmers' intelligence and enables them to perform the farming activities intelligently, accurately and efficiently. Moreover, better educated farmers tend to be more innovative and are therefore more likely to adopt crop livestock integrated production system and marketing. Formal education enhances the information acquisition and adjustment abilities of the farmer, thereby improving the quality of decision making (Fakoyaet al., 2007Astewel (2010) found that if paddy producer gets educated, the amount of paddy supplied to the market increases, which suggests that education improves level of sales that affects the marketable surplus.

Access to market information (MKTINF): As It was hypothesized before access to market information of the household head affected market supply of beef positively and significantly at $1 \%$, Thus, holding other factors constant, on average increases access to market information increasing quantity of beef cattle supplied to the 
market by 0.368 TLU. Farmer's production decision is based on market price information. Poorly integrated markets may convey inaccurate price information, leading to inefficient production. Therefore, it is hypothesized that market information is positively related to market supply. According to Tewodros (2014), market information will be found to influence yield and market supply of agricultural products positively. Therefore, those who have frequency to dynamic information will produce more beef cattle for market. Muhammed (2011) who found that if wheat producer gets market information, the amount of wheat supplied to the market increases.

Distance from feed resources (DISFED): As it was hypothesized before distance of feed resources farm land of the household head affected market supply of beef positively and significantly at $1 \%$, Thus, holding other factors constant, on average decreasing distance to feed resource increasing quantity of beef cattle supplied to the market by 0.019 TLU. Crop residue as a source of livestock feed has begun to rise in recent years, as a result of increased areas of cultivation and changing patterns of leaving land fallow for regeneration. This is especially evident in the highlands where crop cultivation is increasingly intensive and becoming very important (Sintayehu et al., 2010). So, its distance is expected to influence decision to beef cattle production participation and supply of beef cattle negatively. As a sample producer lives far from crop residue area it becomes difficult to produce beef cattle, participate in the market and supply beef cattle to the markets.

Distance from market center (DISMKT): As it was hypothesized before distance to nearest market of the household head affected market supply of beef negatively and significantly at $1 \%$, Thus, holding other factors constant, on average decreasing distance from market center decreases quantity of beef cattle supplied to the market by -0.076 TLU. If closer to the market, the lesser would be transportation cost and time spent. According to Wolday (1994), in his report on food grain market based on research in Alaba Siraro, he argued that poor market access has significant and negative effect on quantity of agricultural food product supply. So, it is hypothesized that distance to market is negatively related with the participation decision in beef cattle production and supply of beef cattle.

Livestock Holding (LIVHH): As It was hypothesized before livestock holding of the household head affected market supply of beef positively and significantly at $1 \%$, Thus, holding other factors constant, on average increases the level livestock holding increasing quantity of beef cattle supplied to the market by 0.038 TLU. It is expected that the TLU of cattle owned by a household could have a significant impact on decision to participate in beef cattle fattening and level of supply of beef cattle to market. It is assumed that household with larger number of beef cattle have better income and financial position to purchase sufficient amount of inputs (Kinde, 2007). It is therefore, hypothesized that it influences decision to participate in beef cattle fattening practice and quantity of beef cattle supply positively.

Use credit (USCRED): As It was hypothesized before credit users of the household head affected market supply of beef positively and significantly at $5 \%$, Thus, holding other factors constant, on average increases the amount of credit users increasing quantity of beef cattle supplied to the market by 0.234 TLU. Credit using within a year that the household head Agricultural service, in our case credit, is believed to enhance the ability of farm households to withstand input supply constraints, encase of liquidity and there by enhance crop choice and productivity (Lerman, 2004). Therefore, a household who has a user to get credit using can be able to buy either farm implements and other inputs which can foster choice and level of crop and/or livestock to be grown or reared and, linking with the use of modern farm technology. Therefore, the more users to credit using, the more it will be market oriented, positive effect. As stated by Zeller and Sharma (2001) and Heidhues and Schrieder (1994), credit adds to the financial resource of the household, for food and input procurement. In the present study, it is expected that households with better access to credit user will be more likely to participate in the beef cattle production and quantity of beef cattle supply.

\section{SUMMARY, CONCULUSION AND RECOMMENDATION 5.1 Summary}

This chapter provides the summary, conclusion and recommendations on the study conducted on value chain analysis of beef in Nono benja district, Jimma zone Oromia regional national state, Ethiopia. The selection of commodity beef over the others in the study areas was made based on the potential as well as the actual/practical conditions of beef production and the marketing trends/habits in the study areas. The specific objectives of the study include identify the factor affecting of farmer's beef cattle market supply. Based on the above objectives the finding of this study is summarized as follows.

The data were generated from both primary and secondary sources. Both qualitative and quantitative data types were collected. The primary data was collected by developing of interview schedule using questioners for farmers (beef cattle producers), small traders, large traders, butchers, hotel/restaurants/ and consumer by using semi-structured and structured questioners. The analysis was made using descriptive statistics and econometric model using STATA 13 software. Therefore, in identifying factor affecting number of beef cattle supply to the market, multiple linear regression model was used in the study was applied to analyze factors affecting market supply of beef cattle in the study areas. 
From 154 interviewed household of beef cattle producer, the average amount of beef supplied by producers was 2.243 in TLU with a minimum amount of 1 and maximum amount of 5 of beef cattle supplied to the market, livestock holding by respondents average 11.07 TLU and minimum and maximum 2.9 and 21.8 TLU, distance to feed resources average 12.14 minutes and minimum and maximum of 3 and 30 minutes from feed resources, non- farm income of house hold average 4119.59 and minimum and maximum of 0 and 30,000 birrs, house hold family size average 4.01 adult equivalent and minimum and maximum of 1.3 and 10.2 adult equivalent, experiences average of 3.26 years and minimum and maximum of 1 and 14 years, distance from market center average of $9.18 \mathrm{~km}$ and minimum and maximum of 1 and $23 \mathrm{~km}$, total land size average $3.04 \mathrm{hr}$. and minimum and maximum of 0.5 and $10 \mathrm{hr}$., education of the house hold minimum of 0 class and maximum of 10 class.

The result of services providers shows that frequency of extension contact was $83.88 \%$ got extension contact one and more than per a month but $16.88 \%$ does not got any extension contact, access to market information $63.63 \%$ got market information while $36.36 \%$ does not got any market information about the market and finally the body condition of beef supplied to the market in this year $74.67 \%$ have good body conformation while $25.33 \%$ have not good body condition according to the answer of respondents.

Twelve variables including Education level of house hold head, distance to nearest market, distance to feed resource, credit using and number of livestock holding were hypothesized to affect marketed supply. Multiple linear regression model analysis was used to analyze factors affecting marketed supply of beef cattle and six variables were found to affect marketed supply significantly. Education of house hold, distance to nearest market, livestock holding, use credit, access of market information and distance to feed resource, are affected marketed supply of beef cattle.

\subsection{Conclusion}

Beef producers need improved input supply system and successful collective marketing of their products. There is need to develop sustainable strategy involving the government, NGOs and farmers in order to increase the production base. The finding of this result shows twelve variables that affects the beef cattle market supply: regarding twelve variables including education level of the household, family size, land size, frequency of extension service, livestock holding, distance to nearest market, distance to feed resource, access to market information, and user credit, experiences and body condition of beef animal were hypothesized to affect marketed supply beef cattle. From the above variables six variables that factors need an intervention; so as to increase possible gain particularly in the study area from beef cattle value chain.

The important factors which were found to be significantly factor affecting market supply of beef in the market, Education of house hold, use credit, access to market information, distance to nearest market, number livestock holding and distant to feed resource; were also influencing the quantity of beef supplied to the market. However, the positive relationship distant to nearest feed resources with beef market supply where positive significant. Hence, these significant factors need to be intervening so as to enhance the possible gain that could be drawn from beef cattle value chain particularly in the study area

The question that now arises and needs to be addressed in order for the productive farmers to become profitable is do they have an access to finance, Strong linkage/interaction among value chain actors, infrastructural support, access to input and knowledge and market. The producers need a special bank service which has low interest to address their particular needs in beef value chain.

\subsection{Recommendation}

The findings of this study enabled us to make the following recommendations for policy makers, developments actors and researchers who have strong interest in promoting value chain and upgrading strategies of beef in the study area. Therefore, appropriate interventions are required to alleviate these problems. To solve the beef cattle value chain and increase production and market supply of beef cattle, the following recommendations are forwarded: The results of value chain analysis and econometric analysis indicate that; -

1. The result of econometric model show that: the increasing of education level of household a positively and significant affect to increase marketed supply, Hence, continuous education and training that would change the production skill of producers is very important to change the attitude of farmers. Therefore, the district education offices and government organizations need to provide continuous education and training on production and marketing of beef.

2. The government should have to be solve the problem of infrastructure since distance to the market is significantly affected the number of beef cattle market supply positively. Thus the far from market should be reduce to the information availability of market and increase transaction cost of the beef cattle producers, so as the distance of market decreases in kilometers the beef cattle supplied to the market is larger. Therefore, in future the government improve the infrastructure for the small beef cattle producers in order access to supply beef cattle to the markets.

3. Distance from feed resource to farmland to provide feed highly significantly affects the number of beef 
cattle supply to the market. Thus the nearest to feed resource is positively influence number of beef cattle sales that affects the market supply positively. On the future animals should have to be nearest to feed resource in order to fatten the animal with in the short period of time and no energy lost for further walking. In addition, animal should get the farm products or residues as well as industrial by products through intensive fattening system.

4. Livestock holding is positively and highly significantly affected the number of beef cattle market supply. Livestock development offices assisting farmers to have large number of livestock through credit or saving, since livestock holding were affecting market supply beef cattle production. Further, livestock are source of income and oxen are tractor of poor rural farmers in the process of crop production.

5. Access of market information is positively and highly significantly affects the quantity of beef supplied. Therefore, trade and industry offices providing timely information for the farmers helps the beef cattle supplied to the market on the right time as well as on the right market price. So improving the market information of the households by keeping other independents variables constant increases the level of beef cattle supplies to the market. Farmer's production decision is based on market price information. Poorly integrated markets may convey inaccurate price information, leading to inefficient production. Therefore, it is hypothesized that market information is positively related to market supply

6. Credit users is a positively and significantly affect market supply of beef cattle. thus provision of credit for small holder producers helps to run the whole Agricultural service and is believed to enhance the ability of farm households to withstand input supply constraints, encase of liquidity and there by enhance crop choice and productivity. Therefore, district micro finance should give credit can be able to buy either farm implements and other inputs which can foster choice and level of crop and/or livestock to be grown or reared and, linking with the use of modern farm technology. Therefore, the more to credit using, the more it will be market oriented, positive effect.so the government create awareness for all beef cattle producers to use credit in order to increase the Beef cattle production and the whole farm activities.

\section{REFERENCES}

Abbey, Avery, (2004). Red Meat and Poultry Production and Consumption in Ethiopia and Distribution in Addis Ababa. Addis Ababa, MSc thesis, Addis Ababa.

Addisu A. et.al,2012. Beef and feed value chain study in Adama district: Value Chain consultant, ILRI September, 2012 Addis Ababa: EIAR, DebreZeit Agricultural Research

Center, Ethiopia Pp.5

Adugna Gessesse, 2009. Analysis of fruit and vegetable market chains in Alamata, Southern Zone of Tigray: The case of onion, tomato and papaya. M.Sc thesis presented to the school of graduate studies, Haramaya University. pp98.

AGP-LMD, 2013. Value Chain Analysis for Ethiopia: Meat and Live Animals, Hides, Skins and Leather and Dairy; Prepared by Agricultural Growth Project-Livestock Market

Ayele Solomon, Workalemahu A, Jabar M A and Belachew H 2003 Livestock Marketing in Ethiopia. A Review of Structure, Performance and Development Initiatives. Socio-economic and Policy Research Working Paper 52. International Livestock Research Institute (ILRI), Nairobi, Kenya. 35p.

Bailey D, Barrett C B, Little P D and Chabari F., 2015. "Livestock markets and risk management among East African pastoralists: a review and research agenda". GL-CRSP Pastoral Risk Management Project Technical Report No. 03/99. Utah State University

Berihu H, Aleme A, Mulata H (2014). Constraints of Livestock Development in Eastern Zone of Tigray; the case of "GantaAfeshumWoreda" Northern Ethiopia. Agricultural

Betselot Mesfin. 2012. Honey value chain analysis with special emphasis to Ada a District. M.Sc thesis, Haramaya University, Haramaya, Ethiopia.

Biruk Jagiso. 2015. Value chain analysis of bee honey and credit market participation of bee keepers: The case of Damot Gale district, M.Sc thesis, Haramaya University, Haramaya, Ethiopia

Bonabana-Wabbi, J., Ayo, S., Mugonola, B., Taylor, D.B., Kirinya, J. and Tenywa, M. 2013. The performance of poultry markets in South Western Uganda. Journal of Development and Agricultural Economics, 5(6): 225-235.

Carina P, (2013) Challenges to Ethiopia's cattle and beef chain. The International Livestock Research Institute (ILRI) has published a report on the challenges faced by Ethiopia's live cattle and beef chain.

Cramer, G. and W. Jensen, 1982. Agricultural economics and agribusiness, 2nd Edition. McGraw Hill Book Company, USA. 222p.

CSA (2005/06) Livestock and livestock characteristics; Private peasant holdings; \# 364, CSA, Addis Ababa, Ethiopia. 
CSA (2008) Research Project ETH/92/P01 Central Statistical Authority (CSA) Addis Ababa, Ethiopia Institute for Population Research - National Research Council (Irp-Cnr) Roma, Italy.

Dolan, C.S. and J Humphrey (2000), 'Governance and Trade in Fresh Vegetables: Impact of UK Supermarkets on the African Horticulture Industry', World Development, 37 (2): 147-77.

Dries, L and J.F.M Swinnen (2004), 'Foreign Direct Investment, Vertical Integration, and Local Supplies: Evidence from the Polish Dairy Sector', World Development, 32(9): 1525- 1544

Elias Mulegeta, Berhanu G, Hoekstra D and Jabbar M 2007 Analysis of the Ethio-Sudan cross-border cattle trade: The case of Amhara Regional State. IPMS (Improving Productivity and Market Success) of Ethiopian Farmers Project Working Paper 4. ILRI (International Livestock Research Institute), Nairobi, Kenya.41 pp.

FAO (Food and Agricultural Organization). 2012. Addressing marketing and processing constraints that inhibit agri-food exports: a guide for policy analysts and planners. Agricultural Service Bulletin 160. Rome. Italy. $109 \mathrm{p}$

FAOSTAT, 2004. Food and Agricultural Organization of the United Nations.; Retrieved July 15, 2004 from FAOSTAT on-line database, http://faostat.fao.org/defualt.jsp?language=EN\& version $=$ ext\& has bulk=0.

Gashahun gezagne, 2015. Beef cattle value chain analysis in case of Darimu district, Ilu Abbor Zone Southe Western of Oromia regional state, Ethiopia. unpublished thesis.

Gebre Mariam S., Amare S., Baker, D., Solomon, A. and Davies, R. 2013. Study of the Ethiopian live cattle and beef value chain ILRI Discussion Paper 23; Nairobi: International Livestock Research Institute international center, Austria. United Nations industrial development organization.

Gereffi, G. 1994. The Organization of Buyer-Driven Global Commodity Chains: How U.S. Retailers Shape Overseas Production Networks, in Gereffi, G. and Korzeniewicz, M. (eds). Commodity Chains and Global Capitalism

Getachew Lagasse., Hailemariam, T., Dawit, A. and Asfaw, N. (2008), Live animal and meat export value chains for selected areas in Ethiopia: Constraints and opportunities for enhancing meat exports, discussion paper No 12, people livestock and environment ILRI.s

Goetz (1992) on food marketing behavior identified better market information significantly raises the probability of market participation.

GTZ (Deutsche Gesellschaftfür Technische Zusammenarbeit GmbH) 2007 Value Links Manual: The Methodology of Value Chain Promotion, First Edition. Found at Internet address http://www.valuelinks. de/manual/distributor.html Hall D.C et al, 2004. The livestock revolution, food safety, and small-scale farmers: Why they matter to us all. Journal of Agricultural and Environmental Ethics, 17: 425-444.

Gujarati, D. 2004. Basic of Econometrics, 4th edition. McGraw hill Company, IN United States Military Academy, West point.

Holloway, G. and S. Ehui, 2002. Expanding market participation among smallholder livestock producers: A collection of studies employing gibbs sampling and data from the Ethiopian highlands. Socio-economic and Policy Research Working Paper 48. ILRI, Nairobi, Kenya. 85p.

Holt,T., 1993. Risk response in the beef marketing channel: a multivariate generalized arch-m approach. American Journal of Agricultural Economics, 75: 559-571.

ILRI (2008) Working Paper No. 19, Cattle milk and meat production and marketing systems and opportunities for market orientation in Fogeraworeda, Amhara region, Ethiopia

Jansen, A. 2007. Value Chain Finance: Understanding and Increasing Access. A Concept Paper. USAID

Kaplinsky R and Morris M 2001 A Handbook for Value Chain Research. Working Paper Prepared for the IDRC, Brighton, UK, Institute for Development Studies.

Kefyalew Alemayew. 2011, Value chain assessment of beef cattle production and marketing in Ethiopia: Challenges and opportunities of linking smallholder farmers to the markets. kefyale@gmail.com

Kohls, R., and N. Uhl, 1985. Marketing of agricultural products. 5th Edition. McMillian Publishing Company, NewYork, USA.

Lerman Z. 2004. Policies and institutions for commercialization of subsistence farms in transition countries. Journal of Asian Economics 15:461-479.

Livestock and Livestock Characteristics. Rep. Vol. II. Addis Ababa: Federal Democratic Republic of Ethiopia, 2012.

LMD Research Interviews and Reports. Unpublished research documents from LMD Research, 2012-13

Million Tadesse, 2014. Factors Influencing the Adoption of Soil Conservation Practices in Wolaita Zone. The Case of Gununo Area MSc Thesis, Department of Agricultural Economics, Alemaya University.

Ministry of Agriculture and Rural Development (2013). Major challenges and Achievements in Ethiopian Livestock production.

Ministry of Agriculture and Rural Development. Agricultural Growth Program (AGP), Program Implementation Manual (PIM). Rep. Addis Ababa: Federal Democratic Republic of Ethiopia, 2010

Miressa Regassa ,2015. Determinant of fertilizer on potato production in case of Nono Benja District Jimma 
zone, Oromia regional state, Ethiopia. unpublished thesis.

MoA (Ministry of Agriculture), 1997b. Ruminant Livestock Development Strategy, Addis Ababa, pp: 87.

Muhammed Urgessa, 2011. Market chain analysis of teff and wheat production in halaba special woreda, southern Ethiopia. M.Sc thesis submitted to the School of Graduate Studies, Haramaya University. 104p.

Negassa, Asfaw. and Jabbar, Mohammad. 2008. Livestock ownership, commercial off-take rates and their determinants in Ethiopia; ILRI Research Report No. 9 Nairobi: ILRI (International Livestock Research Institute). National Bank of Ethiopia 2005/2006

Nigussie Tesfaye, 2014. The Productivity and Profitability of Wheat and Teff Technologies in Selected Villages of Ethiopia. M.Sc. thesis presented to Addis Ababa University, Addis Ababa, Ethiopia. (Read more at http://www.yourdictionary.com/cattle\#y54z4F2ip54FpPCd.99

Oume et al., 2010. feeding animals, health and genotype should improve in Ethiopia

Pastoral Community Development Project (2007). Review of Development Policies and Strategies Related to Pastoral Areas in Ethiopia

Porter ME. 1985. Competitive Advantage. Free Press, New York. Pp.557. Publishing.

Porter, M. 1990, The Competitive Advantage of Nations, The Macmillan Press LTD, London and Basingstoke.

Scott, G.J. 1995. Prices, Products and People: Analyzing agricultural markets in developing countries. Lynne Reinner Publishers, Boulder, London.

Sintayehu et al, 2013. Study of the Ethiopian live cattle and beef value chain, ILRI Discussion Paper No. 23 SPS-LMM (Sanitary and Phytosanitary Standards and Livestock \& Meat Marketing Program). 2009.Unpublished project data and records.

Sintayehu Gebremariam., Samuel Amare., Derek B. and Ayele Solomon., 2010. Diagnostic study of live cattle and beef production and marketing constraints and opportunities for enhancing the system.

Takele et.al, 2009. Traditional Backyard Cattle Fattening in Wolayta: Systems of Operation and the Routine Husbandry Practices. Ethiopian Society of Animal Production (ESAP) ISSN: 1607-3835 Volume 9, Number 1, 2009

Target 2008. Livestock Value Chain Study; Especial Emphasis to DhasWoreda of Borena Zone, Oromia Regional State, Action for Development, Addis Ababa, Ethiopia. Studies by Target Business Consultants Plc.

Teklewold, H., Legesse, G. and Alemu, D. 2009. Market structure and function for live animal and meat exports in some selected areas of Ethiopia. EIAR Research Report No. 79. Addis Ababa, Ethiopia: EIAR (Ethiopian Institute of Agricultural Research).

UNDP-EUE, 2002. A support unit for the United Nations system in Ethiopia, UN emergencies unit for Ethiopia welcome to the UN-EUE home page, Addis Ababa, Ethiopia. World Bank (2002)

Wolday Amha, 1994. Food grain marketing development in Ethiopia after Reform 1990. A Case Study of Alaba Siraro. The PhD Dissertation, Verlag Koster University. Berlin 293p.

Yaicob Aklilu (2007) "An Assessment of Supply and Demand Issues for the Ethiopian Meat Export Industry" (unpublished) Addis Ababa.

Yamane, (1967) P:886

Yigezu, Yared et al 2014. Ethnoveterinary medicines in four districts of Jimma zone, Ethiopia: cross sectional survey for plant species and mode of use. BMC veterinary research, 10(1), p.76. 